\title{
The Effect Of Family and School Cultural Environment Through Self Efficacy on Student Learning Result
}

\author{
Ely Rizky Amaliyah \\ Heri Pratikto \\ Education Studies Program Office Administration State University of Malang \\ Email: ely_amalia20@gmail.com
}

\begin{abstract}
This study aims to explain the relationship between environmental variables out $\mathrm{g}$ a, school culture, self-efficacy and student learning outcomes Administrative Program Program at SMK. This research includes quantitative research type with the explanatory descriptive method. The sampling technique was proportionate stratified random sampling, the study sample consisted of 114 students. Data analysis in this research using path analysis. Results research shows that there is a positive and significant influence of family environment on self-efficacy, there is the positive and significant influence of school culture on self-efficacy, there is a direct positive and significant influence between the environment to the family on the results of learning. While the school culture The air does not directly influence the learning outcomes, but the air of self-efficacy ng driving direct effect on learning outcomes, and the family environment is not aired directly influence the outcome through self-efficacy jar arts students, and school culture has an indirect effect on learning outcomes through students' self-efficacy.
\end{abstract}

Keywords: one family environment, school culture, self-efficacy and learning outcomes

Successful implementation of education requires schools to produce intelligent, innovative, independent, critical and competent learners. Thus, to produce quality learning in the form of mastery of skills and knowledge of Vocational High School Students (SMK) is reflected in the maximum learning outcomes. However, there are some problems to achieve this, such as the result of fewer students learning from KKM (Minimum Exhaustiveness Criteria) of 161 students of class X, XI, and XII, there are 37 students have not achieved the value of KKM in one of the productive subjects of office administration, productive subjects felt less than the maximum. According to information from teacher homeroom teacher and one of the teachers of APK subjects (Office Administration), the cause of less maximum student learning outcomes of APK skills program in SMK Muhammadiyah 5 Kepanjen, the students are lazy to learn, lack of confidence in their ability, individual students, self-motivation to learn, family environment and school environment that affect students' habits at school.

Overcoming the problems that affect the learning outcomes, it is necessary to factor in the factors that influence learning according to Winkel (in Apsari, 2014) suggests factors that affect student achievement comes from internal and external factors. Furthermore, internal factors are factors that come from the individual into intelligence, motivation, attitude or learning style, self-efficacy, interests and physical condition of students. Factors external factors are factors that originate outside the individual self-teachers, family environment, school environment and peer environment.

External factors that effect to the success or failure of students in the process learning is a family environment in the form of parenting ways to educate, harmonious relationships with family members, quiet housekeeping atmosphere, adequate family economic conditions, adequate learning facilities, attention always given parents, 
moral support, tutoring, and understanding of parents (Slameto, 2010: 60). The family environment is the first and foremost influence on one's life, growth, and development. Parents have an important role in educating their children as a guide, teacher and example so as to influence the child's attitude in learning. As research conducted by Sakinah (2014); Park, et al (2017); Yusron (2013) that the family environment has a significant influence on student achievement.

Another external factor is school culture that has supported the success of education. Both, directly and indirectly, have given a touch of treatment to students. The school culture is defined as the way of life in the school that is actually produced by the learner and partly by the teacher. There are two types of school culture: a formal culture that attaches academic achievement as well as benefits to achieve it and informal culture such as culture, speech, etc. (Daryanto \& Tarno, 2015: 5). Each school must have a different school culture. From the results of studies conducted by Thaker and McInerney (in Zazin, 2011: 162) on the test scores of elementary school students show the influence of organizational culture in schools on student achievement. This is in accordance with research conducted by Ramli (2013) that there is a significant positive influence of school culture on the productive competence of students of SMK Negeri Sumatera Barat of $12.7 \%$ and research conducted by Bektas, et al (2015), Pinto, et al 2017) states that by Udaya school has a significant relationship to student achievement.

One of the internal factors in self is self-efficacy. Bandura (in Ghufron and Risnawita, 2011: 75) states that self-efficacy is essentially the result of a cognitive process of decisions, beliefs or expectations about the extent to which individuals estimate their ability to perform certain tasks or actions to achieve desired outcomes. Alwisol (2009: 287) also explains self-efficacy is self-assessment, whether it can do good or bad, right or wrong, can or can not do as required. In accordance with Schunk's opinion (in Santrock, 2009: 216) has applied the concept of self-efficacy on many aspects of student achievement. Students of SMK are prepared to compete in the world of work also requires high self-efficacy. With so students can maximize their learning achievement, form an optimistic attitude and remain persistent in facing every challenge that exists in order to compete in school and the world of work. In line with research conducted by Apsari (2014), Fitriana (2015), Panadero, et al (2017) showed that there is significant influence self-efficacy on student learning outcomes.

The success of a student within learning can be seen from student learning outcomes. Learning outcomes are the abilities students have after receiving their learning experience (Sudjana, 2012: 22). The expected learning outcomes are good learning outcomes because each student wants high yield. But between one student with another student is different in the achievement of learning outcomes. There is capable of achieving high learning outcomes, but there are also students whose learning outcomes are low. This happens because it is influenced by some external factors and internal learning that causes problems and learning difficulties in students.

This study aims to determine: (1) family environmental conditions, school culture, self efficacy and learning outcomes students productive subjects; (2) the influence of the family environment on self-efficacy; (3) the influence of school culture on self-efficacy; (4) the influence of the family environment on learning outcomes; (5) the influence of school culture on learning outcomes; (6) the effect of self efficacy on learning outcomes; (7) the indirect influence of the family environment on learning outcomes through self-efficacy; (8) the indirect influence of school culture on learning outcomes through self-efficacy. 


\section{METHODS}

This research includes quantitative research of descriptive and explanatory type. The dekskriptif analysis is used to analyze the data by describing the data that has been collected while the explanatory research is intended to explain the position of variables studied and the relationship between one variable with another variable. Independent variable in this research is family environment (X1) and school culture (X2), the intervening variable is self-efficacy (Z), while dependent variable (Y) is learning the result. The research design can be seen in the following figure.

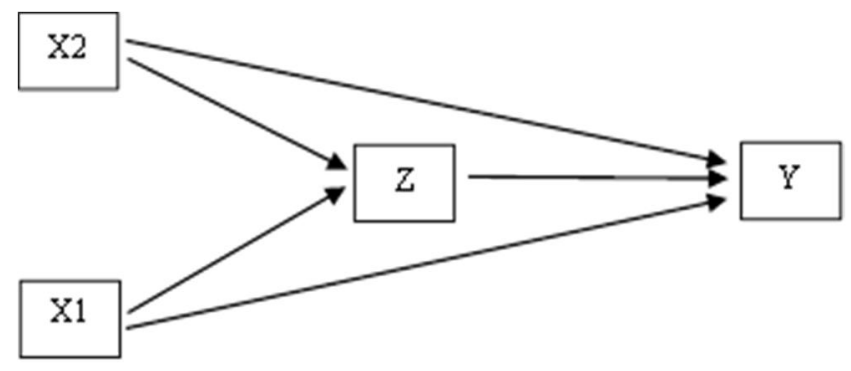

Figure 1. Research Design

The number of population taken as a sample of research as many as 159 students class X, XI and XII expertise program Office Administration SMK Muhammadiyah 5 Kepanjen Malang Regency obtained a sample of 114 students. The sampling technique used proportionate stratified random sampling with the determination of sample size using Slovin formula (Sinambela, 2014: 98). The research instrument using questionnaire/questionnaire with scoring using Likert scale is used to measure attitude, opinion and perception of a person or group about social phenomena (Sugiyono, 2015: 134). Interval of respondent's answer used is number 1 to 5. The instrument test is done by validity test using person product moment formula and reliability test by using Alpha coefficient formula from Cronbach (Sinambela, 2014: 169). After testing the research instrument, validity results obtained 49 valid items from 54 items and the item is declared reliable because of the value of Alpha> label. Data collection techniques used questionnaires and documentation. Data analysis was performed using descriptive statistical analysis and inferential analysis ie path analysis.

Table 1. Criteria of Family Environment Variables (X1), School Culture (X2), and Self Efficacy (Z)

\begin{tabular}{ccc}
\hline Interval Class & Categories X1 and X2 & Category Z \\
\hline $1,00-1,80$ & Very Not Good & Very Low \\
\hline $1,81-2,60$ & Not Good & Low \\
\hline $2,61-3,40$ & Good Enough & High Enough \\
\hline $3,41-4,20$ & Good & High \\
\hline $4,21-5,00$ & Very Good & Very High \\
\hline
\end{tabular}




\section{RESULT \& DISCUSSION}

Based on the result of the frequency distribution for learning result variable shows 81 $(71 \%)$ students get value above KKM that is $\geq 75$ with the highest value equal to 86 and lowest value equal to 70 . Meanwhile, for family environment variable obtained the mean of total respondent answer equal to 4.19 so included in the good category, the school culture variables show the average result of the overall response of respondents amounted to 4.23 so that including the category of very good and self-efficacy variables show the average result of the overall response of respondents of 4.00 so that included the high category.

Based on the research results obtained the results of the classical assumption test normality test showed normally distributed data, multicollinearity test showed that the data in this study did not occur symptoms of multicollinearity and heteroskedastistas test showed that the scatterplot chart does not form a pattern so that it is not free from symptoms of heteroskedastistas. Hypothesis testing in this study using path analysis (path analysis). Here is the result of path analysis in this research.

1. Formulate the structural equation of path analysis and illustrate the path diagram. Model 1: The influence of the family environment and school culture on self-efficacy can be expressed in terms of equations ie $Z=P Z X 1+P Z X 2+e 1$. The path diagram can be described as follows

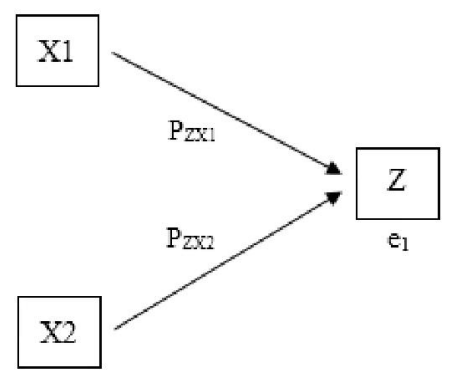

Figure 2. Relationship Model of Variables X1 and X2 Against Z

Model 2: Pengaruh lingkungan keluarga, budaya sekolah dan efikasi diri terhadap hasil belajar dapat dinyatakan dalam bentuk persamaan yaitu $\mathrm{Y}=\mathrm{P}_{\mathrm{YX} 1}+\mathrm{P}_{\mathrm{YX} 2}+\mathrm{P}_{\mathrm{YZ}}+\mathrm{e}_{2}$ dan diagram jalurnya dapat digambarkan sebagai berikut.

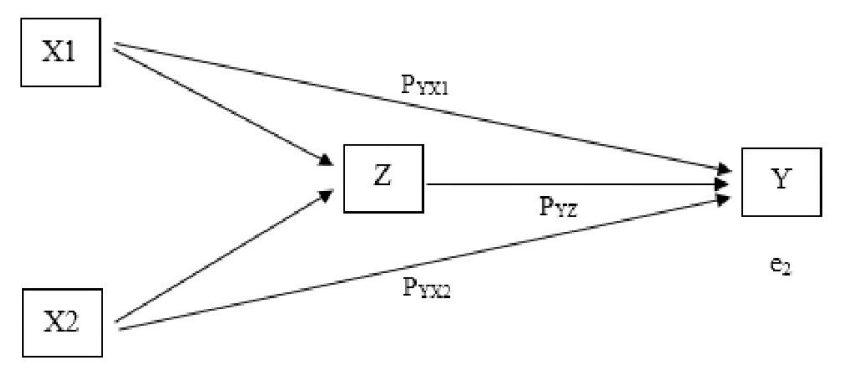

Figure 3. Relationship Model Variables X1, X2 and Z to Y

2. Calculating Standard Error on path analysis Here is the result of multiple regression equations on equation $\mathrm{Z}=\mathrm{PZX} 1+\mathrm{PZX} 2+\mathrm{e} 1$. 
Table 2. Regression Analysis and Recapitulation Result of Path Coefficient Test: Family Environment and School Culture on Self Efficacy

\begin{tabular}{|c|c|c|c|c|c|c|}
\hline \multicolumn{7}{|c|}{ Coefficients $^{a}$} \\
\hline \multirow{2}{*}{\multicolumn{2}{|c|}{ Model }} & \multicolumn{2}{|c|}{$\begin{array}{c}\text { Unstandardized } \\
\text { Coefficients }\end{array}$} & \multirow{2}{*}{\begin{tabular}{|c} 
Standardized \\
Coefficients
\end{tabular}} & \multirow[b]{2}{*}{$\mathrm{t}$} & \multirow[b]{2}{*}{ Sig. } \\
\hline & & $\mathrm{B}$ & Std. Error & & & \\
\hline \multirow[t]{3}{*}{1} & (Constant) & 37,099 & 6,621 & & 5,603 & ,000 \\
\hline & Family environment & ,270 & ,083 & 307 & 3,244 & ,002 \\
\hline & School_Culture & &, 077 & ,298 & 3,147 & ,002 \\
\hline
\end{tabular}

a. Dependent Variable: Self Efficacy

Here is the result of multiple regression equation on equation $\mathrm{Y}=\mathrm{PYX} 1+\mathrm{PYX} 2+\mathrm{PYZ}+$ e2

Table 3. Regression Analysis and Recapitulation of Result of Path Coefficient Testing: Family Environment, School Culture and Self Efficacy on Learning Outcomes

\begin{tabular}{|c|c|c|c|c|c|c|}
\hline \multicolumn{7}{|c|}{ Coefficients } \\
\hline \multirow{2}{*}{\multicolumn{2}{|c|}{ Model }} & \multicolumn{2}{|c|}{$\begin{array}{c}\text { Unstandardized } \\
\text { Coefficients }\end{array}$} & \multirow{2}{*}{$\begin{array}{c}\text { Standardized } \\
\text { Coefficients } \\
\text { Beta } \\
\end{array}$} & \multirow[b]{2}{*}{$\mathrm{t}$} & \multirow[b]{2}{*}{ Sig. } \\
\hline & & $\mathrm{B}$ & Std. Error & & & \\
\hline \multirow[t]{4}{*}{1} & (Constant) & 34,352 & 5,581 & & 6,155 & , 000 \\
\hline & Family environment & ,176 &, 065 & ,262 & 2,723 & ,008 \\
\hline & School_Culture & 100 &, 060 & ,161 & 1,676 & ,097 \\
\hline & Self-efficacy & ,215 & 071 & ,280 & 3,041 & ,003 \\
\hline
\end{tabular}

a. Dependent Variable: Learning Outcomes

3. Estimation of parameters or calculation of path coefficients Based on the calculation in the previous step, there is a direct influence of X1 on Y and the indirect effect of $\mathrm{X} 1$ and $\mathrm{X} 2$ on $\mathrm{Y}$ through $\mathrm{Z}$ as follows.

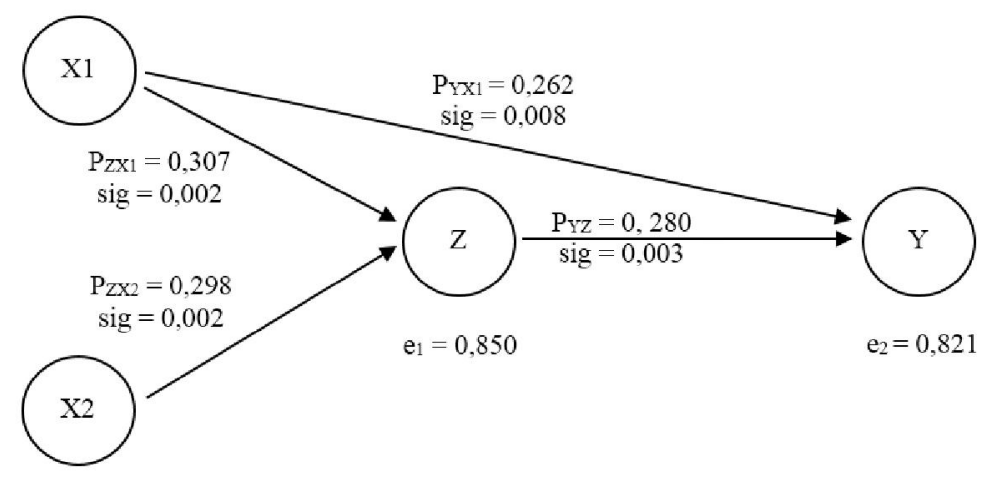

Figure 4. Relationship of Variables X1 and X2 to Y through Z 
4. Check the validity of the path analysis model The diversity of data or information contained in the data is $51.3 \%$, can be explained by the model, whereas the $48.7 \%$ is explained by other variables (not found in the model under study).

5. Understand the results of the analysis To see how much influence directly or indirectly between variables can be seen in Table 3 as follows.

Table 3. Summary of path coefficients, direct and indirect effects, total influence, and the influence of family environment (X1) and school culture (X2) through self-efficacy (Z) on learning outcomes $(\mathrm{Y})$

\begin{tabular}{|c|c|c|c|c|}
\hline \multirow{3}{*}{$\begin{array}{l}\text { Influence of } \\
\text { Variables }\end{array}$} & \multicolumn{2}{|c|}{ Causal Influence } & \multirow{3}{*}{$\begin{array}{c}\text { Rest } \\
\varepsilon 1 \text { and } \varepsilon 2\end{array}$} & \multirow[t]{3}{*}{ Total } \\
\hline & & direct & & \\
\hline & Directly & Through Z & & \\
\hline \multirow[t]{2}{*}{$\mathrm{X} 1$ to $\mathrm{Y}$} & 0,262 & - & - & 0,262 \\
\hline & - & $\begin{array}{c}0,262+(0,307 x \\
0,280)\end{array}$ & - & 0,348 \\
\hline \multirow[t]{2}{*}{$\mathrm{X} 2$ to $\mathrm{Y}$} & 0,161 & - & - & 0,161 \\
\hline & - & $\begin{array}{c}0,161+(0,298 x \\
0,280)\end{array}$ & - & 0,244 \\
\hline Z to $\mathrm{Y}$ & 0,280 & - & - & 0,280 \\
\hline
\end{tabular}

Continued Table 3. Summary of path coefficients, direct and indirect influences, total influences, and family environment influences (X1) and school culture (X2) through selfefficacy (Z) on learning outcomes (Y)

\begin{tabular}{lcccc}
\hline \multirow{2}{*}{$\begin{array}{c}\text { Influence of } \\
\text { Variables }\end{array}$} & \multicolumn{2}{c}{ Causal Influence } & \multirow{2}{*}{$\begin{array}{c}\text { Rest } \\
\text { Indirect }\end{array}$} & Total \\
\cline { 2 - 3 } & \multicolumn{2}{c}{ Ind $\boldsymbol{\varepsilon} 2$} & \\
\cline { 2 - 3 } & Directly & Through Z & & \\
\hline $\mathrm{X} 1 \mathrm{X} 2 \mathrm{Z}$ to $\mathrm{X}$ & 0,326 & - & 0,674 & 1,00 \\
\hline $\mathrm{X} 1$ to Z & 0,307 & - & - & 0,307 \\
\hline $\mathrm{X} 2$ to Z & 0,298 & - & - & 0,298 \\
\hline $\mathrm{X} 1 \mathrm{X} 2$ to Z & 0,278 & - & 0,722 & 1,00 \\
\hline
\end{tabular}

\section{Discussion}

Based on the result of analysis indicate that there are positive and significant influence of family environment variable (X1) to self efficacy variable (Z) student skill program Administration Office SMK Muhammadiyah 5 Kepanjen. This means the better the student's family environment the higher the students' self-confidence in their abilities. This is because the family environment in which there is guidance and attention from parents, and harmony with family relationships. The family is the first and foremost environment of education and provides a basic foundation for learning in the school and community environment (Sukmadinata, 2007: 163). The facilities provided for learning, as well as good family habits can make students feel confident in performing the tasks or actions required for learning. In learning activities, facilities provided by parents is one of the factors that affect the success of learning (Dwija, 2008). A child who is fully supported by the family, especially parents who are always concerned, encouraging, believes that the ability of their children will affect a child's confidence that he can complete schoolwork, exams, and able to face difficulties because of the full support of the parents. Positive thinking training has an influence in improving students' academic self efficacy (Dwitantyanov, 2010).

Based on the results of the analysis indicate that there is a positive and significant influence of school culture variables (X2) on self efficacy variables (Z) students skill program Administration SMK Muhammadiyah 5 Kepanjen. This means that a good 
school culture can affect students' high confidence in their abilities. This is because both men and women have differences in student involvement in school, this is more influenced by the type of activities students follow, norms and values apply (Enccless in Kholid, 2014). The result of revelation of students in the questionnaire of this study on self efficacy indicator states students are confident of the ability that is owned because the school culture supports students in learning. This can also be seen from the characteristics of an effective school, school leaders looking for ways to improve teaching. They find ways to circumvent policies and regulations that limit and hinder academic innovation. Good academic leadership by the principal can build self-efficacy from teacher teaching so as to enhance students' self-efficacy as well (Bandura in Santrock, 2009: 216). Schools with self efficacy are overwhelmed with expectations and high standards for achievement. Teachers consider their students to be able to excel academically, set challenging academic standards for them, and provide support to help them achieve these high standards.

Based on the results of the analysis shows that there is a positive and significant influence directly variable family environment (X1) to learning result variable (Y) productive subjects of students program of administration skill of SMK Muhammadiyah 5 Kepanjen. This is because students who learn will receive influence from the family in the form of parents educate, harmonious relationships with family members, quiet housekeeping atmosphere, sufficient family economic conditions, adequate learning facilities, attention always in the parents, support moral, tutoring, and understanding of parents (Slameto, 2013: 60). The participation of parents great influence on children's learning process and achievement to be achieved. Parents have a role to participate in determining initiative, structured activities at home to complement school education programs (Suharti, 2015). Students always face the family environment and become family members. So if a good family condition it will support the achievement of high learning outcomes (Yusron, 2013). Social support that touches the emotional needs, especially the recognition of the ability and quality of self so that students feel receiving the appreciation and affection of parents have great meaning for students. So the greater the social support of parents who perceived the students, the better academic achievement that can be achieved students (Maslihah, 2011).

Based on the results of the analysis indicate that there is no significant influence directly variable of school culture (X2) to learning result variable (Y) productive subject of student program of administration skill of SMK Muhammadiyah 5 Kepanjen. The absence of a school culture influence on learning outcomes due to the objectives and cultural benefits within a school is to improve consistent behavior and to convey to school personnel how behavior should be done to build their personality in a school environment that is appropriate to the environmental climate created at school (in Daryanto \& Tarno, 2015: 11). The social adjustment of students in the school environment does not indicate a correlation with academic achievement. This indicates the existence of other factors, both internal factors and external factors associated with student academic achievement. The ability of students in social adjustment in the school environment does not have a direct impact on improving student academic achievement, and vice versa (Maslihah, 2011).

Descriptively based on the results of the analysis is known that the school culture is included in the category of very good but the differences in this study with previous research can also be caused by the characteristics of students who differ in responding to the culture applied by the school and the goal of school culture is actually to improve 
the quality standard school. The importance of organizational culture in schools, with regard to achieving the goals of school education and improving school performance. Therefore, school culture has no effect on learning outcomes (Zazin, 2015: 162).

Based on the descriptive analysis of school culture, it is known that from some cultures applied in schools, students feel that the Moving Class culture makes learning ineffective because it will spend time when the process of the class move so that learning becomes less and less time to learn. Just as there is no difference in the result of physics learning of class X students of SMA Negeri 2 Madiun through moving class with the result of physics learning in the morning (Asriyadin, 2012). Some students are disturbed by the arrangement of school events and activities as well as school security both from within such as the enforcement of the rules that are not used as a reference by the citizens of the school and interference from outside the school.

Based on the results of the analysis indicate that there is a positive and significant influence directly variable self-efficacy (Z) to learning result variable (Y) productive subjects of students program of administration skill of SMK Muhammadiyah 5 Kepanjen. This is because students are able to overcome the task results. Students with high self-efficacy learning more easily complete the task, can organize the time well, increase persistence in the face of challenges, have lower anxiety levels, show flexibility in using learning strategies and have the ability to adapt to different learning environments. Positive skills and attitudes that help students in learning activities so that students can achieve learning achievement well (Elmotaleb, 2013). This is also because students feel challenged by difficulties encountered, have strong and steady beliefs to survive in their business, possess strong abilities due to unsupported experiences and have confidence in their abilities in varied situations. The more difficult a task, the higher the desire to be diligent in developing themselves (Ilhamsyah, 2014).

The difficulties faced by the students in learning activities indicate the lack of confidence in him/her. So that in each of the students need to have self-efficacy that can affect the size of the business, selected activities and patience to have confidence in its ability. It is suspected that it would be more effective to improve mathematics learning achievement if done by generating self-efficacy first. So that learner have confidence that he can understand and master the subjects of mathematics (Widyaninggar, 2014)

Self-efficacy affects students' choice of activities. Students with low self-efficacy in learning can avoid many challenging learning tasks. While students with high selfefficacy face the learning task with great desire. Students with high self-efficacy are more diligent in the learning task compared to students with low self-efficacy (Schunk in Santrock, 2009: 216).

Based on the analysis result indicating that there is the indirectly significant influence of family environment variable (X1) through self-efficacy (Z) to learning result variable (Y) productive subject of student skill program Administration Office SMK Muhammadiyah 5 Kepanjen. This is because a good family environment and support affects the level of students' confidence in their ability so that with the recognition of parents, students are able to complete school tasks, students will feel have a responsibility to achieve maximum learning outcomes. Each individual has the ability to influence a person in shaping one's beliefs, either consciously or unconsciously, one of which the parents have a considerable share in shaping students' self-confidence (Suharti, 2015). 
The self-efficacy of a child supported by the family environment, such as by seeing the experiences or success of parents and their brothers is able to foster strong belief in a child so motivated to study hard and provide the best learning outcomes to imitate parents and his brother who has succeeded. Social support that touches the emotional needs, especially the recognition of the ability and quality of self so that students feel receiving appreciation and affection of parents have great meaning for students (Maslihah, 2011). Self-efficacy can be obtained, altered, enhanced or derived, through one or a combination of four sources, namely the experience of master achievement, vicarious experience, social persuasion and emotional generation (Alwisol, 2009: 288).

Based on the results of the analysis indicate that there is a significant influence indirectly variable of school culture (X2) through self-efficacy (Z) to learning result variable (Y) productive subject of student skill program Administration Office SMK Muhammadiyah 5 Kepanjen. This is because students expressed confidence in the ability they have because the school culture supports students in learning. Self-efficacy variables function as a variable that reinforces the relationship between school culture and learning outcomes. Self-efficacy combines with the environment, previous behaviour, and other variables, especially expectations of results to produce something. Self-efficacy will affect some aspects of cognition and behaviour of a person (Ghufron \& Risnawita, 2011: 75). The environment in question can be a school environment in which there is a culture that has been implemented in schools. Social adjustment of good students in the school environment has a positive impact on students' emotional condition or provide positive energy for students (Maslihah, 2011).

Self-efficacy variables in this study as intervening variables that serve to strengthen the relationship between school culture and learning outcomes. Selfefficacy mediates the relationship between perceived academic climate and students' academic performance (Elmotaleb, 2013) and self-efficacy to meditatively demonstrate both direct and indirect influence on achievement motivation and learning strategies (Yusuf, 2011).

In school culture, there are indicators related to teachers related to the management of learning activities in the form of strategy implementation, media utilization and learning resources as well as teacher acceptability to new learning method. Based on student questionnaire results stated that the management of teacher learning activities and acceptability are included in the very good category. This is also due to the cultural relationship of schools in the management of learning activities. that the ability to transfer the subject matter is one aspect of the self-efficacy of teaching, but the self-efficacy of teaching also includes the belief that one can maintain an orderly classroom that is a fun place to learn so that students feel the spirit of learning and have the confidence to complete school tasks and trying to achieve maximum learning outcomes (Santrock, 2011: 216).

\section{CONCLUSIONS \& RECOMMENDATIONS}

Based on the results of research and discussion, it can be concluded that the family environment of the students of the program of administration skills of SMK Muhammadiyah 5 Kepanjen is included in the good category, the school culture in SMK Muhammadiyah 5 Kepanjen included in the category of excellent self-efficacy and the students of the administration program of SMK Muhammadiyah 5 Kepanjen in the high 
category, while for the learning result of students' productive subjects are included in either category. There are a positive influence and significance of family environment variable to self-efficacy variable of a student of Office Administration skill program at SMK Muhammadiyah 5 Kepanjen There are a positive influence and significance of school culture variable to self-efficacy variable of a student of Office Administration skill program at SMK Muhammadiyah 5 Kepanjen. There is a direct positive and significant influence on a family environment variable to the variable of learning result of the productive subject of a student Office Administration skill program at SMK Muhammadiyah 5 Kepanjen. There is no significant influence on the variables of school culture on the variable of learning result of productive subjects of the students of the Office Administration skill program at SMK Muhammadiyah 5 Kepanjen. There is a direct positive and significant influence on self-efficacy variables to the variable of learning result of the productive subject of a student Office Administration skill program at SMK Muhammadiyah 5 Kepanjen. There is indirect influence between family environment variable to the variable of learning the result of the productive subject through the self-efficacy of student of Office Administration skill program at SMK Muhammadiyah 5 Kepanjen. There is an indirect influence between school culture variables on the variables of learning achievement of productive subjects through selfefficacy of students of the Office Administration skill program at SMK Muhammadiyah 5 Kepanjen.

Suggestions that researchers can provide, among others, for parents should pay more attention to the learning process of children when at home with more set the child's learning time, ask lessons learned at school and take time to accompany learning. For the Head of SMK Muhammadiyah 5 Kepanjen, the headmaster should reconsider the moving class culture that is less effective in learning, emphasizing school security both on and off and paying attention to school schedule so as not to interfere with learning activities. For teachers, teachers should improve the learning outcomes of productive subjects of students of SMK Muhammadiyah 5 Kepanjen so that all students can achieve the value of KKM by improving students' self-confidence that will become graduates who are ready to work through encouragement and motivation to the students. For students it is better for students to increase their confidence in their ability to perceive difficult productive subjects, strive to complete tasks with their own ability without asking for help from friends and fostering the spirit to work on productive subjects tasks.

\section{REFERENSI}

Alwisol. 2009. Personality Psychology. Malang: UMM Press. (Indonesian Origin).

Apsari, B. S., Adi, W. and Octoria, D. The Effect of Self Efficacy Using Learning Style and Environment of Peers on the Achievement of Accounting Learning (Case Study in SMK Negeri 1 Surakarta). Journal of Education UNS, (Online), 3 (1): 91-102, (http://jurnal.fkip.uns.ac.id), accessed October 16, 2016. (Indonesian Origin).

Asriyadin, F. 2012. Influence of Moving Class And Learning In The Morning Against Physics Learning Results. Journal of Faculty of Teacher Training and Education. Thesis not published. Yogyakarta: Post-graduate of Ahmad Dahlan University Yogyakarta. (Indonesian Origin). 
Bektas, F., Cotalgay, N., Karadag, E., and Ay, Y. 2015. School Culture and Academic Achievement of Student: A Meta-Analysis Study. Anthropologist, (Online), 21 (3): 482-488, (http://journal.unnes.ac.id/sju/index.php/eeaj), accessed 05 October 2016. (Indonesian Origin).

Daryanto and Tarno, H. 2015. School Culture and Climate Management. Yogyakarta: Gava Media. (Indonesian Origin).

Dwija, I, W. 2008. Relationship Between Self Concept, Achievement Motivation and Parents Attention With Sociology Learning Outcomes In Second Grade High School Students In Amlapura City. Journal of Education and Teaching, (Online), 11 (1) Th.XXXXI,

//journal.undiksha.ac.id/index.php/JPP/article/view/1977/1724), accessed April 23, 2017. (Indonesian Origin).

Dwitantyanov, A., Hidayati, F., and Sawitri, D. R. 2010. Influence of Positive Thinking Training on Student Self Academic Self-efficacy (Experimental Study on Student of Psychology Faculty Undip Semarang). Jurnal Psikologi Undip, (Online), 8 (2): 135144, (http://ejournal.undip.ac.id/index.php), accessed February 27, 2017. (Indonesian Origin).

Elmotaleb, M. A. and Saha, S. K. 2013. The Role of Academic Self-Efficacy as a Mediator Variable between Perceived Academic Climate and Academic Performance. Journal of Education and Learning, (Online), 2 (3): (118-129), (http://citeseerx.ist.psu.edu/viewdoc/citations), accessed 27 February 2017. (Indonesian Origin).

Ghufron, M.N. and Risnawita, R.S. 2011. Psychological Theories. Yogyakarta: Ar-Ruzz Media. (Indonesian Origin).

Ilhamsyah, 2014. Effects of Self Efficacy, Metacognition and Regulation. (Indonesian Origin).

Self Against Achievement Learning Mathematics Student Class X Sma Negeri in Wajo District. Journal of Teacher Training and Education (JKIP, (Online), 1 (1): 10-20, (http://fkip.unismuh.ac.id/e-jurnal/index.php/jkip/article/view/2), accessed April 23, 2017. (Indonesian Origin).

Khalid, A. 2015. Relationship Self Efficacy and Peer Support with Student Involvement in Schools. Thesis not published. Surakarta: Post-Graduate University of Muhammadiyah Surakarta. (Indonesian Origin).

Maslihah, Sri. 2011. Studies on Social Support Relationships, Social Adjustment in School Environment and Academic Achievement of SMPIT Students Assyfa Boarding School Subang Jawa Barat. Jurnal Psikologi Undip, (Online), 10 (2): 103114, (http://ejournal.undip.ac.id/index.php/psikologi/ article / view / 2848/2532), accessed April 23, 2017. (Indonesian Origin). 
Panadero, E., Jonsson, A., Botella, J. 2017. Effects of self-assessment on self-regulated learning and self-efficacy: Four meta-analyses. Educational Research Review. Vol 22 (Nov.): 74-98. (Indonesian Origin).

Park, S., Stone, S.I., Holloway, S.D. 2017. School-based parental involvement as a predictor of achievement and school learning environment: An elementary schoollevel analysis Author links open overlay panel. Children and Youth Services Review. 82 (Nov): 195-206. (Indonesian Origin).

Pinto, G., Bigozzi, L., Vettori, G., Vezzani, C. 2017. The relationship between conceptions of Learning and Academic outcomes in middle school students according to gender differences. Learning, Culture and Social Interaction. Available online 29 November 2017. (Indonesian Origin).

Ramli. 2013. The Effect of School Culture on Productive Competence of Students of SMK Negeri Sumatera Barat. Journal of Scientific Education, (Online), No.2: 307-314, (http://journal.uny.ac.id/index.php/cp/article/view/1489), accessed 05 October 2016. (Indonesian Origin).

Sakinah, N. and Haryati, Y.T. 2014. The Effect of Learning Discipline, Learning Motivation, and Family Confusion on Student Achievement of Economics Subject of Students of Class X SMAN 2 Kudus Tahun Ajaran 2013/2014. Economic Education Analysis Journal (EEAJ), (Online), 3 (2): 379-384, (http://journal.unnes.ac.id/sju/index.php/eeaj), accessed 05 October 2016. (Indonesian Origin).

Santrock, J. W. 2009. Educational Psychology Issue 3 Book 1. Jakarta: Salemba Humanika. (Indonesian Origin).

Santrock, J. W. 2009. Educational Psychology Issue 3 Book 2. Jakarta: Salemba Humanika. (Indonesian Origin).

Sinambela, L. P. 2014. Quantitative Research Methodology; For Science Administration Sector, Public Policy, Economy, Sociology, Communication and Other Social Sciences.Yogyakarta: Graha Science. (Indonesian Origin).

Slameto. 2010. Learning and Factors Affecting it. Jakarta: Rineka Cipta. (Indonesian Origin).

Solimun, M.S. 2002. Structural Equation Modeling (SEM) Lisrel and Amos. Malang: State University of Malang. (Indonesian Origin).

Sudjana, N. 2012. Assessment of Teaching and Learning Process Results. Bandung: Teens Rosdakarya. (Indonesian Origin).

Sugiyono. 2015. Educational Research Methods (Quantitative Approach, Qualitative and R \& D). Bandung: Alfabeta. (Indonesian Origin). 
Suharti, Darwis, M., and Suwardi, A. 2015. The Effect of Democratic Patrons, Peer Social Interaction, Emotional Intelligence and Self Efficacy on Student Learning Outcomes of Grade VIII SMPN Se-Kecamatan Manggala in Makassar City. Mathematical Power Journal, (Online), 3 (1): 10-19, (http://ojs.unm.ac.id/index.php/JDM/ARTICLE/ VIEW / 1292), accessed February 20, 2017. (Indonesian Origin).

Sukmadinata, N. S. 2007. The Platform of Psychology of Education Process. Bandung: Teens Rosdakarya. (Indonesian Origin).

Widyaninggar, A, A. 2014. The Effect of Self Efficacy and Full Locus (Locus Of Control) on Mathematics Learning Achievement. Journal Formative, (Online), 4 (2): 89-99, (http://digilibmercubuana.ac.id/isi_artikel), accessed April 23, 2017. (Indonesian Origin).

Yusron, M. 2013. Effect of Learning Styles and Family Environment on Students' Learning Outcomes Economics Competency Basic Accounting Students Class XI IPS in SMA AL-IRSYAD Pekalongan Year 2012/2013. Economic Education Analysis $\begin{array}{lllll}\text { Journal (EEAJ), } & \text { (Online), } & 2 & \text { (2): }\end{array}$ (http://journal.unnes.ac.id/sju/index.php/eeaj), accessed 05 October 2016. (Indonesian Origin).

Yusuf, M. 2011. The impact of self-efficacy, achievement motivation, and self-regulated learning strategies on students' academic achievement. Procedia Social and Behavioral Sciences. (Online), 15: 2623-2626. (http://www.sciencedirect.com/science/article), accessed January 28, 2017. (Indonesian Origin).

Zazin, N. 2011. Movement of Quality Education: Theory \& Application. Jogjakarta: ArRuzz Media. (Indonesian Origin). 